\title{
THE BEST MODEL OF ECONOMIC GOVERNANCE IN MANAGING OLD WELL
}

\author{
Noto Pamungkas dan Sri Suryaningsum \\ Accounting Department, Economic and Business Faculty, \\ Universitas Pembangunan Nasional "Veteran" Yogyakarta. \\ J1. SWK (104) Lingkar Utara, Condongcatur, Yogyakarta, DIY. 55283 \\ Telp. +62274486733 \\ Email: srisuryaningsum@upnyk.ac.id
}

\begin{abstract}
This research is to analyzethe management of oil and gas old well in Wonocolo. Bojonegoro is really unique and interesting to be observed. The latest plan is that this area will be purposed into sustainable development to protect the environment in its surrounding, more over, this area is aimed to be a tourism object. The researchers hope that the result of this research gives significant contribution, especially in terms of good economic governance, for management of old oil and gas in Wonocolo if the minersswitched tothe tourism sector.The activity of traditional mining in this area cannot be strained from by year. The negative effects which appear are damaged environment, mining activity legality, unstrained pollution, insecurely working, and other social problems. Based on this thoughtfulness, the government of Bojonegoro endeavours the idea of enlightening the traditional miner, exploiting it to be educational system of oil and gas management (educational tourism). This activity needs to be socialized well, to change the habit of traditional miners to be tourism agent. The aim of this research is to give idea or contribution to rearrange the oil and gas old well that has been already exist, especially the object of this research is in Wonocolo, Bojonegoro. Oil and gas old well mining is not merely to process oil and gas mining, but more than that, the existence of it can support the economic condition of local citizens and also repair the infrastructure independently. Because of this, the local income and prosperity of local people will be increase, and the poverty will be decrease.
\end{abstract}

Keywords: oil and gas tourism, local economy, traditional mining of oil and gas old well in Wonocolo, Bojonegoro

\section{INTRODUCTION}

The aim of this writing is to explain the good economic governance in maintaining educational tourism object, based on oil and gas old well in Wonocolo, Bojonegoro. The researchers hope that the result of this research gives significant contribution, especially in terms of good economic governance, for management of old oil and gas in Wonocolo that has already existed. It is appropriate to Suyoto (2015), Sunaryadi (2015) and Suryaningsum (2015), which the existence of educational tourism object based on old well mining in Wonocolo is a part of sustainable development concept, also as the endeavour of environment protection. Suyoto (2015) and Sunaryadi (2015) stated that traditional mining of old well in Wonocolo cannot be strained by year, The negative effects which appear are damaged environment, mining activity legality, unstrained pollution, insecurely working, and other social problems. Based on this thoughtfulness, the government of Bojonegoro endeavours the idea of enlightening the traditional miner, exploiting it to be educational system of oil 
and gas management (educational tourism). This activity needs to be socialized well, to change the habit of traditional miners to be tourism agent.

The management of oil and gas old well in Wonocolo, Bojonegoro is really unique and interesting to be observed. The latest plan is that this area will be purposed into sustainable development to protect the environment in its surrounding, more over, this area is aimed to be a tourism object. The researchers hope that the result of this research gives significant contribution, especially in terms of good economic governance, for management of old oil and gas in Wonocolo that has already existed. Hopefully, well maintenance of Wonocolo old well will lead this area to be the best model or sequential project for other old wells in Indonesia.

\section{THEORY}

There is an effort of Bojonegoro government to upgrade the quality of human resources, so that they will be more independent, by exploring and exploiting their potencies and environmental potencies, to achieve good opportunity in economy, politic and society. Inability in exploring and exploiting the potencies caused villagers left behind and trapped into poverty, more over, there is no ability to build the ability and the quality of the youth. Unqualified human resources impacts multidimentional poverty, it means that they are voicelessness (as they have low education level), powerless (as they have not only low education level but also low skill), so that they cannot catch the opportunity in economy, politic and social in their life.

The empowering of economy in local (village) development hopefully develops the productive trading diversivication, so that there will be more job field for local people, especially in the activity of off-farm and nonfarm agribusiness, also small until mid service industries, as it is suited to the local potencials. The positive effects to be reached are the decreasing of unemployments and poverty level. Other effects are the increasing of local people's productivity and income. A good combination of society instancies and local government in development management will raise the opportunity of society and local social-economy instancies in supporting local sustainable development. Becasue of this, the instancies is formed into corporate which share beneficial toward the society such as supply financial capital, supply production tools, maintenance of farming tools and machines, manufacture the product, and marketing product. The corporation also develops the trading (off-farm and non-farm), which are suited to the local potencials. BUMDesa is economy instancy which has to proactive start from up-stream until down-stream in the activity of plantation development and the other productive economy activities that are done by local people suited to local potencial also. A qualified and professional BUMDesa is the one which is independent and has good job networking with a lot of parties as the effort of build local economy to be more independent and autonomous.BUMDesa as local economy instancy also help the increasing of real local income (PADesa) and it support local development in increasing prosperity independently. BUMDesa is public instancy, and it works independently and professionally, to share it beneficial to all of its members.

The organizational of this writing is preceded by the background of study, method, result and discussion, conclusion and future research agenda, reference, and acknowledgment. The governance phenomenon is discussed in background of study. The discussion topic of this writing is the role of government and the economic governance. The role of government is as a supportive side in changing the local people's point of view, as they used to be traditional miners, to be tourism agents. While economic governance focus on what and how is the role of BUMDesa.

\section{RESEARCH METHOD}

This research is conducted by the method of case study. Observation, library research, and in-depth interviews conducted for more 
than a year, January 2015 to Februari 2016. Earlier research (Suryaningsum, at al 2014a, 2014b) stated that Bojonegoro was chosen as the research object because Bojonegoro got 18 awards in 2014. The Regent was awarded as innovative regional leader by Sindo newspaper in 2014.

At the first time Suyoto served as Bojonegoro Regent, he realized that the level of citizens' reliance toward the previous government was low, because of there were some problems in the bureaucracy. Since then, Suyoto tried to do a significant change of governance/bureaucracy, to reach a better government with the hope that the citizens could respect and support them again.

This research aims to answer the research question: how Bojonegoro regent alleviate the poverty of traditional miners in Wonocolo? How Bojonegoro protect and preserve its nature? How is the economic management?

\section{RESULT AND DISCUSSION}

The analysis in this writing consists of some definitions, ways also innovations that are done by Suyoto the regent in developing Wonocolo, Bojonegoro start from 2008. The focus is to achieve cultural and social assets for all Bojonegoro people. It is done by applying some programs, such government roles and constructing the BUMDesa.

\section{The Existance of Government}

Suyoto (2016) said that Bojonegoro is not competing with anybody, only with hope and growing public desire. There is no persistence. Because everyone has historic responsibility to fill that hope, making a better life. The government of Bojonegoro presents to take care the traditional miners in Wonocolo to support their work performance and facilitate them by repairing the road, supply the object of health, worship, toilet, parking area, and communication network. In doing these efforts, the government of Bojonegoro works together with all of departments to achieve Wonocolo as tourism object. The Department of Culture and Tourism is the main agent while the Department of Energy and Mineral Resources Bojonegoro (Dinas ESDM) is the one who has the field work. Both of these departments are working together to creat tourism object based on education of oil and gas in Wonocolo.

The pioneering effort of educational tourism of oil and gas old well in Wonocolo is the excellent potency to be developed in Bojonegoro. The potency of it should be well-maintained by BUMDesa with clear law, which is Village Regulation about Service Maintenance of this object.

Government Regulation no. 72, 2005; section 79; subsection 2; about BUMDesa asset stated that the sources of BUMDesa asset are:

a. Local government

b. Citizens/members' savings

c. Government's assistant (province government and or region government)

d. Loan

e. Other assets or profit shares.

Based on these principles, the sources of Wonocolo BUMDesa are:

1. Local asset that is separated from local income and cost (APBDesa), and local financial instancy.

2. The asset from local government and other legal assets's sources which have been already arranged by regulation.

3. The asset of third party which has been managed in BUMDesa basic estimation.

4. Loan asset through financial instancy, bank, and other sources as it is concurred by BPD as the regulator.

The reason why BUMDesa was built was market certainty in Wonocolo with in cooperationwithmany parties (Suyoto, 2015a) in order to quicklydevelop inthe tourism economy. 


\section{Economic Governance in Managing Old Well}

According that Suryaningsum at. Al (2015a, 2015b), the existence of BUMDesa is optimalized to empower local potencials and fulfil the local needs, such as keep the stock of basic needs, clean water, communication network, and interaction accessibility with other villages. Partial industries of local people are not accommodated well and they still have certain obstacle such as financial assets, production management, marketing, and there are still unoptimal exploration. The existence of BUMDesa in Wonocolo is purposed to facilitate the village to be more independent and autonomous. It also supports to increase village real income (PADesa). The higher PADesa the better village be, because PADesa helps vilage's activities, and it will motivate to liberate itself from the government.

Based on this aim, the local empowering is focused on self-sufficient and indenpendency of maintenance funding, and funding for village development. A good village development will affect the live quality of local people. A good PADesa helps the village itself to plan and realize the development, achieve the prosperity and get out from poverty. It is because the village itself has ability to fulfil the infrastructures and significant facilities independently.

BUMDesa is local financial instancy which supports local development by empowering local people. It helps local work/ industry through consolidation of economic activity. According to this fact, both BUMDesa and local people shoul support each other so that those progresses can be advance.

There are some ways to strengthen the existence of BUMDesa in Wonocolo, Kedewan, Bojonegoro as the basic economic power:

1. The upgrading of capacity and ability of local people (human resources).

2. Integrating local industries and supporting them to be more competence in the market.

3. Grouping the local industries, so that there will be good atmospher of economic development.

4. Upgrading the quality of local industries.

5. Helping the development of local industries in Wonocolo, Kedewan, Bojonegoro is oil and gas sector by supplying financial assets through micro-credit.

6. Filtering market information and held training together with the one who competent on it. With these ways, hopefully the power of local economy will build stronger and be independent.

BUMDesa as local instancy contributes the increasing income for the real village income (PADesa), so the village itself will be able to achieve prosperousity independently. The existence of BUMDesa should be supported by all of aspects od citizen in Wonocolo, Kedewan, Bojonegoro. It should be independent and professional in supporting all of the activity of citizens. The team work of them is the best way to creat mutualism symbiosis.

The founding of BUMDesa must notice some principles according that Government Regulation no. 72, 2005, they are:

a. BUMDesa in each region is operated in different ways, according to the potencial, capacity and the needs of local people. The field of the work/ industry is suited to the resources (human resources, natural resources, technology, asset, market and also information) that are owned. The work/industry which is maintained by BUMDesa should be beneficial for all of citizens, together with the solution of the problem that possibly happen.

b. BUMDesa should give the priority to the citizens as members. It is called as collective purpose in economic development. The existence of BUMDesa is fully supported by the 
power of citizes (social) rather the power of domination/authorization. The local people are empowered through the activity on the work/ industry under BUMDesa. It is as the evidence of local power streng. It shows that the local people always push themselves to be better in knowledge and skill, to be independent, liberate from external help, especially cetral government.

c. BUMDesa should be supported participatively and initiatively by local people. Hopefully the existence of BUMDesa helps local people, increase the public service. BUMDesa also tries to list the all of the potencial and resources of village.

The participation of all citizens in Wonocolo, Kedewan, Bojonegoro will be the power to build village economic development sustainably.

a. BUMDesa is built and maintained to fulfil economic development needs, give benefit for all of citizens, give an open opportunity for their work/ industry and give special attention to the poorers. Its benefits are used to fulfil the needs of education, healthiness, village infrastructure and other development fields. It helps the existence work/industry, support them to be independent and success.

b. BUMDesa respect the system of democratic and other systems/values that are believed in certain area. With the spirit of democration, BUMDesa always support local people's work/ industry, and also invite them to share their aspiration. It respect honesty, harga diri, other's voice (aspiration, suggestion, criticism), give priority to the public interest, and does not discriminate others.

c. BUMDesa is accountable and transparent instancy. The activity and the process in it can be guaranted and can be controlled by local government and the citizens. All of informations and policies can be accessed openly, so it becomes the responsible of entire citizens.

d. The aim of BUMDesa existency in Wonocolo, Kedewan, Bojonegoro is to support local economic potency to help the local people. One of the roles of BUMDesa is to decrease the jobless by opening new job field and increase citizens' poverty. Various local potencies and assets (human resources and natural resources) are supported by the existence of various BUMDesa. These variousity mighb be formed into organization, the source of asset, and other thing related. Moreover, BUMDesa also should notice norms and local wisdoms which are obtained by certain area. The important principle of BUMDesa is that this instancy should place public interest and the value of helping. BUMDesa appears to give some helps for local people, so that they can manage monetary circulation. A good monetary circulation will create dynamic economic situation. Hopefully local economic condition will be better and better. The reason why BUMDesa was built was market certainty in Wonocolo with in cooperationwithmany parties (Suyoto, 2015a), like thatSKKMigas, Pertamina, tourism community, and government It means that local people cannot access the market certainty in certain time. Some cases that often happen is that the broker takes more advantages rather than the real farmers/the firsn producers. This condition must be stopped, by strengthening the asset source, market network (input and output). 


\section{CONCLUSION}

The development of educational tourism object by managing oil and gas old well in Wonocolo, hopefully will be the best model of sequential object for others old well minings. The aim of this research is to give idea or contribution to rearrange the oil and gas old well that has been already exist, especially the object of this research is in Wonocolo, Bojonegoro. Oil and gas old well mining is not merely to process oil and gas mining, but more than that, the existence of it can support the economic condition of local citizens and also repair the infrastructure independently. Because of this, the local income and prosperity of local people will be increase, and the poverty will be decrease.

BUMDesa as local economy instancy also help the increasing of real local income (PADesa) and it support local development in increasing prosperity independently. BUMDesa is public instancy, and it works independently and professionally, to share it beneficial to all of its members.

As the researchers stated before that the principles of BUMDesa are based on local value, empowerment of local people (as the main power of BUMDesa itself, to achieve collective purpose in developing economy condition), and the value of participation and inisiative of local people.
BUMDesa is one of stimulant to support local economy and the impact of it, BUMDesa should upgrade the public services for all. It is believed that Wonocolo people are having the most understanding of oil and gas old mining knowledge, so they have to be involved directly and actively. The support of all local aspect will help the development of educational tourism object in oil and gas old well in Wonocolo.

\section{ACKNOWLEDGEMENT}

The researchers' deepest gratitude go to Drs. Suyoto, M.Si. (the Regent of Bojonegoro, East Java, Indonesia), Drs. Soehadi Moeljono, M.M. (Sekda Bojonegoro), Drs. Setyo Yuliono, Drs. Gatot Sugiono, M.M., Agus Suprihanto, S.H., M.M., Amir Syahid, S.Sos, Sigit Rahardjo, Agus Amperiyanto, Nurul Azizah, S,Sos., Ir. Cahya Edi Nusantara, M.M., Rahmat Junaidi, M.Si., Saleh Fathoni, S.Sos., Dyah Enggar Rini, dan Suyanto.The entire of Bojonegoro local government, Bojonegoro District, DIKTI KEMENRISTEKDIKTI RI, LPPM University of Pembangunan National "Veteran" Yogyakarta, Accounting Department of UPN "Veteran" Yogyakarta, and Economic Faculty of UPN "Veteran" Yogyakarta. Due to the process of this paper writing, we deeply thank to the research assistant, Rakyan Widhowati Tanjung.

\section{REFERENCES}

Basri, Mutia Yesi. (2007). Pengaruh Pengetahuan Dewan tentang Anggaran Pada Pengawasan Keuangan Daerah. Jurnal Ilmu administrasi Negara, Volume 9, Nomor 1, Januari 2008, 29-39.

Dinas ESDM Kabupaten Blora. (2015). Sharing Pengalaman Kegiatan Sumur Tua di Kabupaten Blora. FGD Pengelolaan Sumur Tua.

Direktur Jenderal Minyak dan Gas Bumi Kementerian ESDM. (2015). Pengembangan Sumur Tua dan penanggulangan Ilegal Driling.

Indriyati. Etty. (2014). Pola dan Akar Korupsi. Gramedia Pustaka Utama.

Macinko, J., Starfield, B. and Shi, L., (2003). The contribution of primary care systems to health outcomes within Organization for Economic Cooperation and Development (OECD) countries, 1970-1998. Health services research, 38(3), pp.831-865.

Muat, Muhammad. Demokrasi Ala Bojonegoro. (2014). [Online] Available at: http:// 
politik.kompasiana.com/2014/03/19/demokrasi-ala-bojonegoro-640505.html[online] (Accessed 2 April 2015)

Prayitno, Sayoga. Heru. (2015). Peluang dan Tantangan Pengelolaan Sumur Tua.

Roqib, Muhammad. (2014). http://www.koran-sindo.com/read/932217/149/petinggi-embungyang-doyan-ngetrail-1417577276 [online] (accessed on 8 April 2015)

Scharmer, C.O., (2013a). Addressing the blind spot of our time: an executive summary of the new book by Otto Scharmer" Theory U: leading from the future as it emerges". Social Technology of Presencing.

Scharmer, C.O. and Kaufer, K.(2013b). Leading from the emerging future: From ego-system to eco-system economies. Berrett-Koehler Publishers.

Schwenke S. (2005). Sectoral Systhesis. In Spector, Bertram I. (Ed) Fighting Corruption in Developing Countries. Strategies and Analysis. Kumarian Press, Inc. Bloomfield, Connecticut, pp. 152-180.

Sunaryadi, Amien. (2015). Konsep Pengelolaan Kawasan Sumur Tua Wonocolo dengan Desa Wisata sebagai Added Value.

Suryaningsum, Sri., Moch. Irhas Effendi. and R. Hendri Gusaptono. (2015a). Bojonegoro District, The Best Governance Role in Indonesia's Economic Development and Poverty Alleviation. Paper presented at USM-ICOSS 2015, Malaysia, 27-28 August 2015.

Suryaningsum, Sri., Moch. Irhas Effendi. and R. Hendri Gusaptono. (2015b). 'Tata Kelola Pemerintahan dan Potensi Sumber Daya Bojonegoro untuk Meningkatkan Kesejahteraan', Proceedings of Economic \& Social of Seminar Nasional Call Paper dan Pameran Hasil Penelitian \& Pengabdian Masyarakat Kemenristek DIKTI RI, Yogyakarta, Indonesia.

Suryaningsum, Sri., Moch. Irhas Effendi. and R. Hendri Gusaptono. (2015c), 'The Role of Poverty Allevation in Bojonegoro: Flood Well-maintain',Journal of Economic \& Social, LPPM UPNVY.

Suryaningsum, Sri., Moch. Irhas Effendi. and R. Hendri Gusaptono. (2014a). 'Pengentasan Kemiskinan Berbasis Pro-Poor Government dengan Sisi Transformasional', Journal of Ekonomi dan Keindonesiaan: Membangun Ekonomi Pro-Rakyat.

Suryaningsum, Sri., Moch. Irhas Effendi. and R. Hendri Gusaptono. (2014b), Tata Kelola Penanggulangan Kemiskinan, Gosyen Publishing.

Suryaningsum, Sri. Jangan Gantungkan Pendapatan dari Migas. (2016). http://www.antarajatim. com/berita/172523/sri-suryaningsum-jangan-gantungkan-pendapatan-dari-migas

Suyoto. (2015). Pengelolaan Sumur Tua di Wilayah Bojonegoro.

Suyoto. (2016). Yang Tercecer dari Kang Yoto. Proses Terbit.

Suyoto. (2015a). Jawaban Pertanyaan untuk Sri Suryaningsum. Manuskrip.

Suyoto. (2015b). Strategi Pengelolaan Pemerintah Daerah. Semnas Pembangunan Indonesia UPN "Veteran" Yogyakarta. 17 April 2015.

Suyoto. [Online] Available at: http://bojonegorokab.go.id/berita/baca/110/ENAM-ELEMENPEMBANGUNAN-BERKELANJUTAN-BOJONEGORO- [online] (Accessed 2 April 2015)

Wardono, Ahmat Wahyu. (2015). Peningkatan Keselamatan Migas Pengusahaan Sumur Tua. 